\title{
Comparative Analysis of the Mechanical Properties of Matrix Based on Polyester Composites Reinforced with Particulated, Continuous and Aligned Tauari Fiber (Couratariguianensis)
}

\author{
Rilmar Pereira Gomes ${ }^{1}$, Jandecy Cabral Leite ${ }^{2}$, Roberto Tetsuo Fujiyama ${ }^{1}$, Raimundo Valdan Pereira Lopes ${ }^{1}$ \\ rilmargomes@hotmail.com, jandecy.cabral@itegam.org.br, fujiyama@ufpa.br, valdanlopes@hotmail.com \\ ${ }^{1}$ Programa de Pós-Graduação em Engenharia Industrial da Universidade Federal do Pará (PPGEI-ITEC-UFPA) \\ ${ }^{2}$ Instituto de Tecnologia e Educação Galileo da Amazônia (ITEGAM)
}

\begin{abstract}
The Tauari is another natural fiber researched in order to analyze the mechanical properties of polymeric composite materials manufacturing process. This paper targeted the mechanical properties evaluation of materials based on polyester composites reinforced with particulate tauari fiber of $10 \mathrm{~mm}$ and $15 \mathrm{~mm}$ long. The polyester composites reinforced with continuous and aligned tauari fiber also were included at the present research. The fibers used at the experiments did not pass through any kind of chemical process during the composites manufacturing process, the entire manufacturing was made manually and the mass proportion used by the fibers inside each composite were: $10,58 \%-10 \mathrm{~mm}$ particulate tauari fiber; $5.22 \%-15 \mathrm{~mm}$ particulate tauari fiber. The results of the traction tests presented that the mechanical resistance of the composite increased when the length of the fiber used was increased and the fibers had a better alignment which increased the fiber-matrix contact. The results of the traction tests were: $10 \mathrm{~mm}$ particulate tauari fiber - 18,84MPa; $15 \mathrm{~mm}$ particulate tauari fiber - 19,08MPa; aligned and continuous tauari fiber 19,20MPa. Such results were compared with another natural fiber from previous researches using the quantity and quality method and was concluded that the polymeric composites reinforced with tauari fiber or other materials using the tauari fiber can be applied at the industrial environment at many sectors.
\end{abstract}

Key words: Tauari fiber (Couratariguianensis); polymeric composite; mechanical resistence, traction experiment.

\section{Análisis comparativo de las propiedades mecánicas de Matrix Composites Reforzados poliéster a base de partículas añadidas con, continua y Alineados fibra Tauari (Couratariguianensis)}

\section{RESUMEN}

El Tauari es otra fibra natural investigado con el fin de analizar las propiedades mecánicas del polímero proceso de fabricación de materiales compuestos. En este trabajo se dirige a las propiedades mecánicas de los materiales de evaluación basado en composites de poliéster reforzado con fibra de partículas tauari de $10 \mathrm{~mm}$ y $15 \mathrm{~mm}$ de largo. Los materiales compuestos de poliéster reforzado con fibra de tauari continua y alineada también se incluyeron en el presente estudio. Las fibras utilizadas en los experimentos no pasar por ningún tipo de proceso químico durante el proceso de fabricación de materiales compuestos, toda la fabricación se ha realizado de forma manual y la proporción de masa utilizado por las fibras dentro de cada compuesto fueron: 10,58\% - $10 \mathrm{~mm}$ de fibra tauari partículas; 5,22\% - $15 \mathrm{~mm}$ de fibra tauari partículas. Los resultados de las pruebas de tracción presentan que la resistencia mecánica del material compuesto aumentó cuando se incrementó la longitud de la fibra utilizada y las fibras tenido una mejor alineación que aumentó el contacto fibra-matriz. Los resultados de los ensayos de tracción fueron: $10 \mathrm{~mm}$ de fibra de partículas tauari - 18,84MPa; $15 \mathrm{~mm}$ de fibra tauari partículas - 19,08MPa; alineado y fibra tauari continua - 19,20MPa. Estos resultados se compararon con otra fibra natural de investigaciones anteriores que utilizan el método de cantidad y calidad, y se concluyó que los materiales compuestos poliméricos reforzados con fibra tauari u otros materiales que utilizan la fibra tauari se pueden aplicar en el entorno industrial en muchos sectores.

Palabras clave: Fibra tauari (Couratariguianensis), compuesto polimérico, resistencia mecánica, tracción experimento. 
Rilmar Pereira Gomes et al./ITEGAM-JETIA Vol.01, No 04, pp.46-52. Dezembro, 2015.

\section{INTRODUCTION}

The advances of the modern technology resulted at an indiscriminate and uncontrolled increase of the natural reserves consume, the side effects of this fact have been reflected at the climatic unbalance, the increase of the planet temperature (global warming) and other effects [1]. Concerned with the environment issues more advances in the technology stimulated the growth of the consumer market where the industries seek for new solutions to manufacture new materials to compose versatile products that can meet the sustainability and the economic growth in compliance with the present environment legislation that encourages the use of biodegradable raw materials at the industrialized products that are not aggressive to the environment [2].

This scenario pushed the researches to follow the environment concern in order to discover new environment friendly materials. These conditions were the basis of the new biodegradable materials that have been discovered lately such as the renewable sources [3], among these new discovered materials the composite materials already was created with the concept of biodegradable using the natural resources to be applied at the industrial environment to increase the number of biodegradable composite products making the production of the industries selfsustainable, reducing the operation costs by changing the raw material and increasing the degradability of the products in comparison with another synthetic materials [4]. Due the fact that the composites are materials that are obtained from the combination of others the definition of multiphase material can be applied and the properties of each phase becomes evident and the combination of each property make the composite material present improved properties in comparison to each individual phase [5]. The composite materials play an important role at the materials evolution due the fact that these materials are the starting point to develop products that combine materials with excellent mechanical and non aggressive properties to the nature in order to reduce the impact caused by the synthetic materials discarded at the environment [6]. During the materials research process, the Amazon Forest is highlighted due the fact of the high diversity of plants that hold important properties for materials manufacturing. Following this same line of research it was found the Tauari (Couratari spp.), a plant commonly found at the lands of Brazilian states like Pará, Amazonas, Amapá and Roraima, it is part of the Lecythidaceae family, known as toari, imbirema [7]. The tauari fibers have been used at the Amazon region for rope manufacturing and other materials.

At each study performed to find new composite materials is possible to observe the evolution of the mechanical properties of the biodegradable materials [8], for example the composite materials manufactured using polyester matrix and reinforced with curauá fibers with the respective lengths of $5 \mathrm{~mm}$, $10 \mathrm{~mm}$ and $20 \mathrm{~mm}$ manually processed without chemical process application presented the following results at the traction resistance tests respectively of $13.60 \mathrm{MPa}, 17.70 \mathrm{Mpa}$ and $14.50 \mathrm{MPa}$, in comparison with the chemical processed curauá fibers the traction resistance results of the $10 \mathrm{~mm}$ and $20 \mathrm{~mm}$ presented respectively the values of $19.30 \mathrm{MPa}$ and $22.20 \mathrm{MPa}$ [9]. The composites composed by epoxy matrix and reinforced with banana fibers of $15 \mathrm{~mm}$ presented the result of $16.12 \mathrm{MPa}$ at the traction resistance test [10].

The main objective of this paper is to present the mechanical properties of the composites based on polyester matrix and reinforced with $10 \mathrm{~mm}$ and $15 \mathrm{~mm}$ length of tauari fibers and compare the results with another polymeric composites reinforced with natural fibers.

\section{MATERIALS \& METHODS - EXPERIMENT}

Polyester Resin: It was used a pre-accelerated resin of cobalt naphthalene (CaNap), using a mass proportion of $0.15 \%$. This insaturated terephthalic polyester is produced by the Royal polimeric industry under the commercial name of Denverpoly 754. The curing agent applied was the MEK peroxide (Butonax M-50), under the proportion of $0.33 \%$ (v/v) [11].

The Tauari Fiber: The Tauari fiber was manually extracted from an adult tree near Itacoatiara county away from Manaus (Amazonas state capital) $267 \mathrm{Km}$. The basic tools used to perform the extraction were sickles and machetes to remove part of the tree peel. The removal process of the fiber was done by submerging the peels of the wood in a container with water during $12 \mathrm{hrs}$ to enable the manual shredding of the fiber. Considering that the extraction process was made manually using scissor and stiletto as tools we observed that the fiber acquirement is very simple and low cost, this process was conducted by the same way as the local residents do to acquire the tauari fiber. The fibers were cut in $10 \mathrm{~mm}$ length and $15 \mathrm{~mm}$ length and were separated. The entire procedure of extraction and the forming of the fibers were performed in the Composite Materials Laboratory of the Mechanical Engineering College from the Federal University of Pará - UFPA.

Tauari Fibers Characterization: The Tauari fibers characterization were based at the traction resistance, extension, length, diameter, specific mass, moisture content, superficial aspects and the fiber microstructure. The microstructure inspection was performed using a Scanning Electron Microscope - SEM where the superficial aspects and the cross section of the samples could be analyzed. It is worth to highlight that during the characterization the tauari fibers were classified like in natura. The average diameter of the fibers were performed using an optical microscope where two measures of the longitudinal way could be taken from 20 samples of the tauari fibers [1]. The lengths of the particulated composites follow the measure of $10 \mathrm{~mm}$ and $15 \mathrm{~mm}$. The specific mass of each fiber length followed the determination of the respective proportions: $10.58 \%$ - $10 \mathrm{~mm} ; 5.22 \%$ - $15 \mathrm{~mm}$.

The figure 1 presents the images of the longitudinal and frontal angle of the fiber taken from SEM where the microcavity of the fiber surface could be observed [12]. To determine the humidity/absorption percentage the fibers of tauari were exposed to a drying process at an electric oven during 15 minutes. The oven model used was LayrMidy Inox and the determination of the humidity percentage was performed using 2 fiber samples with a total mass of 34.50 grams. To determine the humidity percentage the initial weight of the fibers was measured and the samples were dried until reach the constant mass value. 

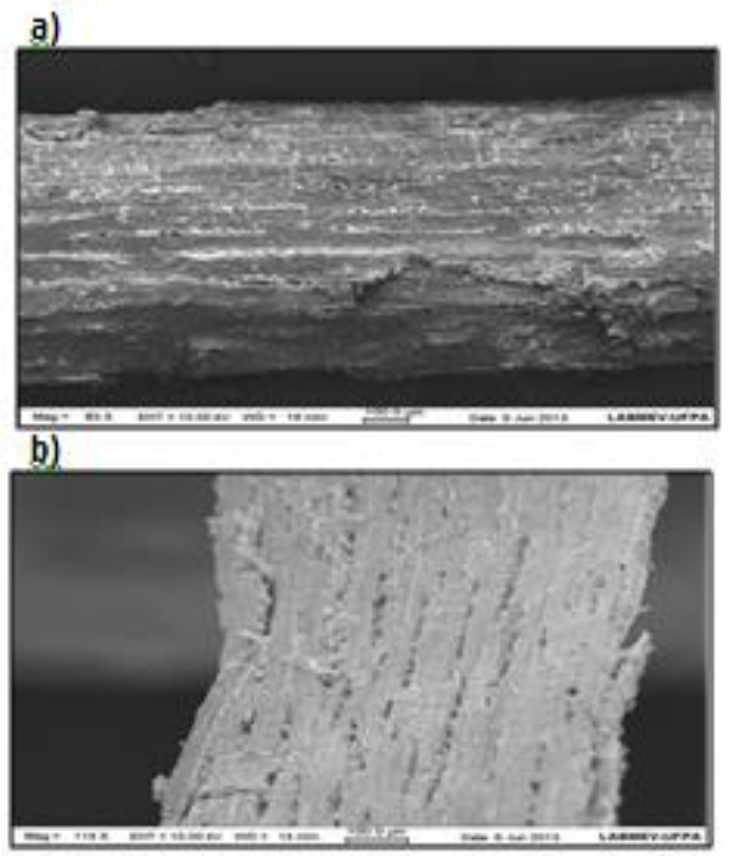

c)

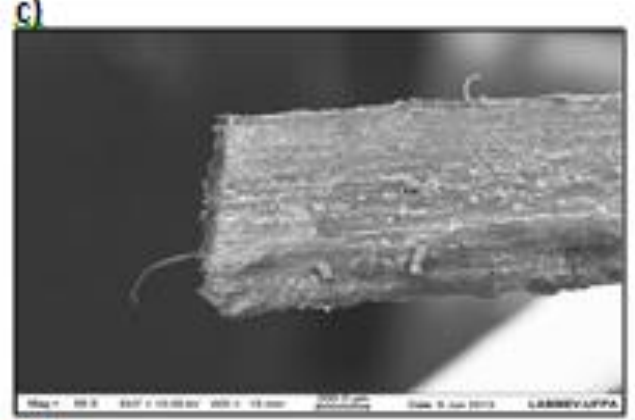

d)

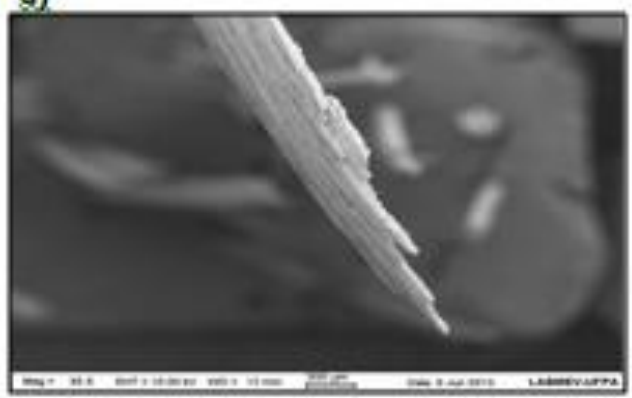

Figure 1. Images taken from SEM of the in natura tauari fiber: a) longitudinal angle, b) superficial microcavity of the fiber, c) and d) frontal angle of the fiber.

Production of the test samples: A manual and low cost molding process was used to execute the composite test samples production where a demolding and pressureless process using silicone molds followed the steps: mass proportion determination of the fiber, molding of the test samples, curing and grinding [13].

The specific mass value of the tauari fibers was measured according to the fiber length using a Marte model precision balance from Marte Balança e Aparelhos de Precisão LTDA [14]. The mass fractions of the $10 \mathrm{~mm}$ length and $15 \mathrm{~mm}$ length tauari fibers were distributed inside the composite according to the mold volume capacity.

The composites were manufactured using a pre-optimized polyester matrix where the $10 \mathrm{~mm}$ and $15 \mathrm{~mm}$ particulated tauari fibers were homogeneously mixed with a previously weighted resin quantity together with the curing agent inside a Becker during 5 minutes and placed at the silicone molds in an ambient temperature [14][15], the same process was performed to manufacture the composites reinforced with continuous and aligned fibers.

As mentioned in [14] the traction molds were filled with $10 \mathrm{~mm}$ length and $15 \mathrm{~mm}$ length reinforcing tauari fibers until reach the volume capacity of the molds using a manual process without mechanical vibration or pressure application and after the molding process each reinforment was weighted to acquire the mass value and converted to mass fraction to be used as reference at the pressureless composites manufacturing process. These data were used to establish a reference proportion of the composites reinforced with the tauari fibers.

After the determination of the mass fraction reference value the test samples were manufactured and used at the liquid state evaluation of the mixture workability where the wettability and the moldability of the polyester matrix over the reinforcing fibers were observed. Using this method was possible to determine the mass fraction of the $10 \mathrm{~mm}$ and $15 \mathrm{~mm}$ tauari fiber previously made. The mass fraction determined for the $10 \mathrm{~mm}$ and $15 \mathrm{~mm}$ tauari fiber were respectively $10.58 \%$ and $5.22 \%$. Each manufactured test sample was mixed with the curing agent in a proportion of $0.33 \%(\mathrm{v} / \mathrm{v})$ following the recommendations of [16].

Traction testing of the composite material: Where used silicone molds to manufacture the test samples which were used 24 samples of composite materials based on polyester matrix reinforced with shorten tauri fibers. The traction tests were performed at the UFPA laboratory using the model KRATOS

MKCA-KE an universal traction machine from KRATOS COF Equipamentos Indústrias with a data acquisition system and a $5 \mathrm{KN}$ load cell. The test samples were fixed and locked at the lower and upper case of the machine holder in an average contact point of $60 \mathrm{~mm}$ of the sample body. It was applied a traction velocity of $5 \mathrm{~mm} / \mathrm{min}$. The test procedure followed the recommendations of [16].

\section{RESULTS}

Mechanical characterization of the composite materials: The entire mechanical characterization process of the tauari fiber composite was developed following the ASTM D 638 standard [16].

Composite materials reinforced with $10 \mathrm{~mm}$ tauari fiber: The Mechanical properties of the composite material based on polyester matrix and reinforced with $10 \mathrm{~mm}$ tauari fibers acquired from the traction tests can be found at the table 1 which displays a higher traction resistance limit. 
Table 1. Mechanical properties of the composite material based on polyester matrix and reinforced with $10 \mathrm{~mm}$ tauari fibers traction test results.

\begin{tabular}{|c|c|c|c|}
\hline $\begin{array}{c}\text { Corpos de } \\
\text { Prova }\end{array}$ & $\begin{array}{c}\text { Maximum } \\
\text { Force } \\
(\mathbf{k N})\end{array}$ & $\begin{array}{c}\text { Maximum } \\
\text { Strain } \\
(\mathbf{M P a})\end{array}$ & $\begin{array}{c}\text { Deformação } \\
(\mathbf{m m} / \mathbf{m m})\end{array}$ \\
\hline Mean & 0,91 & 18,84 & 0,04 \\
\hline $\begin{array}{c}\text { Std } \\
\text { Deviation }\end{array}$ & 0,11 & 1,63 & 0,01 \\
\hline
\end{tabular}

The chart in the figure 2 shows that typical tension versus strain behavior of the composite material based on polyester matrix and reinforced with $10 \mathrm{~mm}$ tauari fibers.

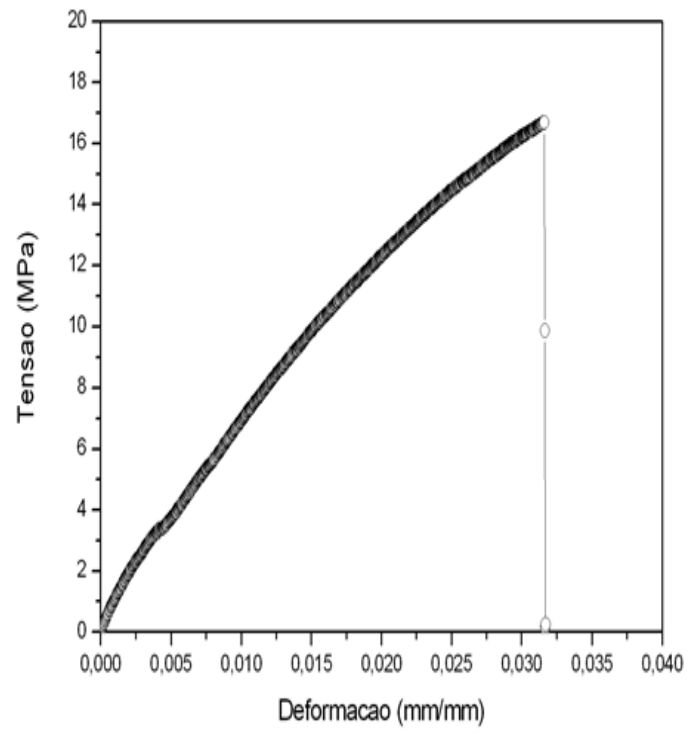

Figure 2. Typical behavior of the composite material based on polyester matrix and reinforced with $10 \mathrm{~mm}$ length tauari fibers.

Composite materials reinforced with $15 \mathrm{~mm}$ tauari fiber: The table 2 shows the results of the resistance test to mechanical traction of the composite reinforced with $15 \mathrm{~mm}$ tauari fiber.

Table 2. Mechanical properties of the composite material based on polyester matrix and reinforced with $15 \mathrm{~mm}$ tauari fibers traction test results.

\begin{tabular}{|c|c|c|c|}
\hline Test Sample & $\begin{array}{c}\text { Maximum } \\
\text { Force } \\
(\mathbf{k N})\end{array}$ & $\begin{array}{c}\text { Maximum } \\
\text { Strain } \\
(\mathbf{M P a})\end{array}$ & $\begin{array}{c}\text { Deformation } \\
(\mathbf{m m} / \mathbf{m m})\end{array}$ \\
\hline Mean & 1,07 & 19,08 & 0,03 \\
\hline $\begin{array}{c}\text { Std } \\
\text { Deviation }\end{array}$ & 0,09 & 2,65 & 0,01 \\
\hline
\end{tabular}

The tests were performed using 7 test samples of the composite materials and analyzing the results it is possible to identify an increase of the traction resistance limit in $0.24 \mathrm{MPa}$ in comparison with the composite material reinforced with $10 \mathrm{~mm}$ tauari fiber.

The chart in the figure 3 shows the tension versus strain typical behavior of the composite material based on polyester matrix and reinforced with $15 \mathrm{~mm}$ length tauari fibers.

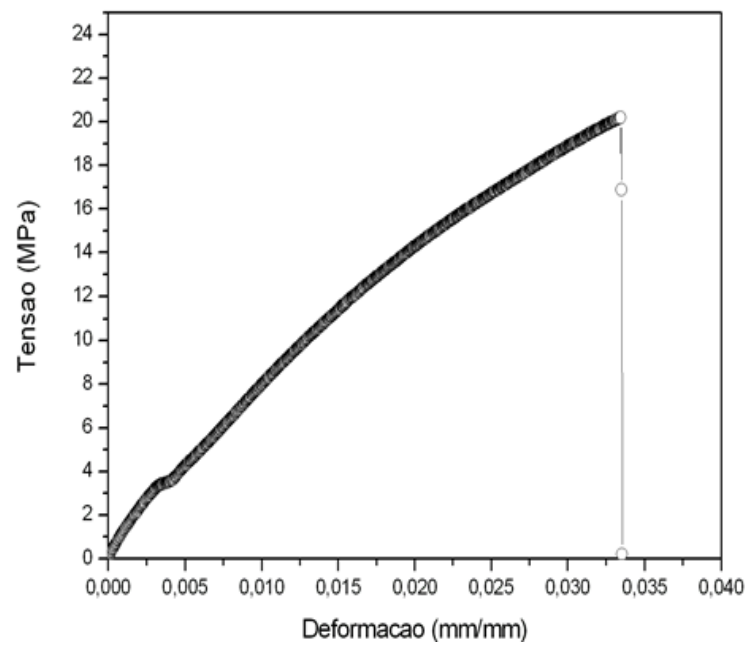

Figura 3. Force $(\mathrm{N})$ versus extension $(\mathrm{mm})$ of the composite materials reinforced with $15 \mathrm{~mm}$ tauari fibers

Composite materials reinforced with continuous and aligned tauari fiber: The table 3 presents the results of the resistance test to mechanical traction of the composite reinforced with continuous and aligned tauari fiber

Table 3. Mechanical properties of the composite material based on polyester matrix and reinforced with continuous and aligned tauari fibers traction test results.

\begin{tabular}{|c|c|c|c|}
\hline $\begin{array}{c}\text { Test } \\
\text { Sample }\end{array}$ & $\begin{array}{c}\text { Maximum } \\
\text { Force }(\mathbf{k N})\end{array}$ & $\begin{array}{c}\text { Maximum } \\
\text { Strain } \\
\text { (MPa) }\end{array}$ & $\begin{array}{c}\text { Deformation } \\
(\mathbf{m m} / \mathbf{m m})\end{array}$ \\
\hline Mean & 0,41 & 19,20 & 0,02 \\
\hline $\begin{array}{c}\text { Std } \\
\text { Deviation }\end{array}$ & 0,09 & 3,21 & 0,00 \\
\hline
\end{tabular}

The tests were performed using 13 test sample of the composite materials reinforced with continuous and aligned tauari fibers. The chart presented at the figure 4 represents the typical tension versus strain behavior of the manufactured composite.

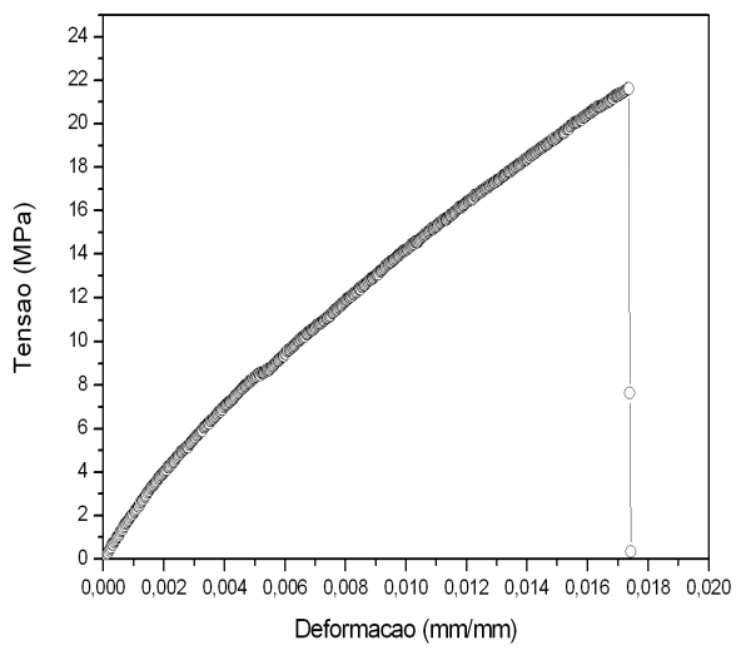

Figure 4. Force $(\mathrm{N})$ versus extension $(\mathrm{mm})$ of the composite materials reinforced with continuous and aligned tauari fibers. 


\section{RESULTS DISCUSSION}

During a comparative analysis of the acquired data of the tables 1,2 and 3 is possible to observe that the mechanical resistance limit of the composite materials based on polyester matrix and reinforced with $15 \mathrm{~mm}$ tauari fiber increased $0.24 \mathrm{MPa}$ in comparison with the composite materials based on polyester matrix and reinforced with $10 \mathrm{~mm}$ tauari fiber. When the results of the composite materials based on polyester matrix and reinforced with continuous and aligned tauari fibers were compared with the previous composites it was possible to identify that the mechanical resistance limit increased $0.12 \mathrm{MPa}$ in comparison with $15 \mathrm{~mm}$ tauari composites and 0.36 in comparison with $10 \mathrm{~mm}$ tauari composites. Observing such results it is possible to confirm what was stated for [3] that longer fiber lengths increase the superficial contact matrix-fiber that increase the mechanical resistance of the composites. The table 4 presents the entire results acquired during the traction tests of the test samples developed during this research.

Table 4. Mechanical properties of the composite materials based on polyester matrix reinforced with $10 \mathrm{~mm}, 15 \mathrm{~mm}$, continuous and aligned tauari fibers.

\begin{tabular}{|l|l|l|c|c|c|}
\hline \multicolumn{1}{|c|}{ \#CP } & Force (kN) & $\begin{array}{c}\text { Displacem } \\
(\mathbf{m m})\end{array}$ & $\begin{array}{c}\text { Max Tension } \\
(\mathbf{M P a})\end{array}$ & $\begin{array}{c}\text { Elasticity Module } \\
(\mathbf{G P a})\end{array}$ & Deformation (mm/mm) \\
\hline \multicolumn{7}{|c|}{$\mathbf{1 0 , 0}$ mm length Fiber } \\
\hline Mean & 0,91 & 2,36 & 18,84 & 0,48 & 0,04 \\
\hline Std dev. & 0,11 & 0,36 & 1,63 & 0,05 & 0,01 \\
\hline \multicolumn{7}{|c|}{$\mathbf{1 5 , 0 ~ m m ~ l e n g t h ~ F i b e r ~}$} \\
\hline Mean & 1,07 & 1,95 & 19,08 & 0,60 & 0,03 \\
\hline Std dev. & 0,09 & 0,39 & 2,65 & 0,06 & 0,01 \\
\hline \multicolumn{7}{|c|}{ Continuous \& Aligned Fiber } \\
\hline Mean & 0,41 & 1,46 & 19,20 & 1,24 & 0,02 \\
\hline Std dev. & 0,09 & 0,30 & 3,21 & 0,16 & 0,00 \\
\hline
\end{tabular}

The variation of the mechanical resistance of the composite reinforced with particulated $10 \mathrm{~mm}$,
$15 \mathrm{~mm}$ and the continuous and aligned tauari fibers can be observed at chart of the figure 5 .

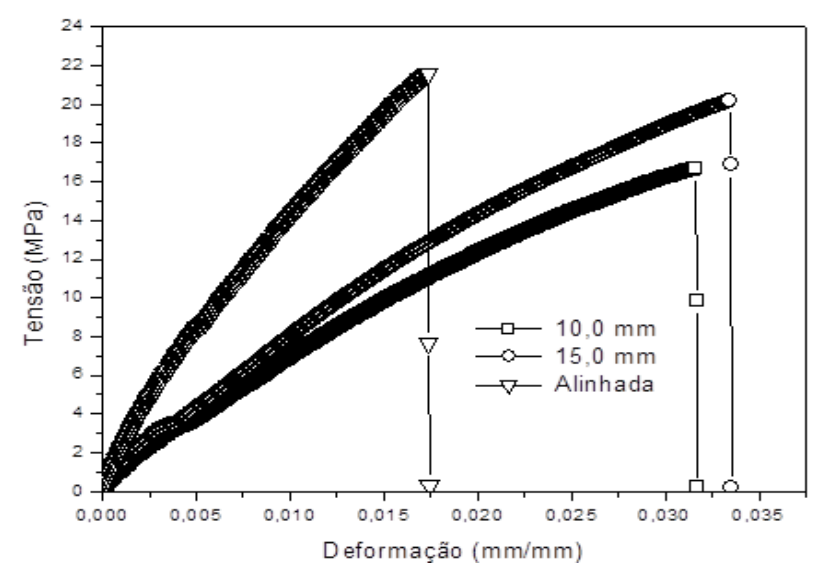

Figure 5. Tension versus strain chart of the composite reinforced with particulated $10 \mathrm{~mm}, 15 \mathrm{~mm}$ and the continuous and aligned tauari fibers.

Among many researches using natural fibers to manufacture composite materials it was not found any reference to the tauari fibers in the state of the art. However many other fibers like sisal, bamboo, banana, carauá and etc already have been used during scientific research.

The present research results were compared with the results of previous studies using another types of natural fibers. The first research had the objective to develop the manufacturing process of hybrid composites using sisal fiber mixed with wood sediments but in fact the research led to the development of 2 different composites. The first composite was based on polyester matrix reinforced with sisal fibers and the second composite was also based on polyester matrix but reinforced with maçaranduba sediment. The composite materials reinforced with sisal fibers were manufactured following the respective fiber length of $5 \mathrm{~mm}, 10 \mathrm{~mm}$ and $15 \mathrm{~mm}$ with the respective mass proportion of $5.41 \%, 4.87 \%$ and $3.90 \%$ and presented the following traction resistance limits of $15.27 \mathrm{MPa}, 23.48 \mathrm{MPa}$ and 
26.16MPa. The mass proportion of the composite materials reinforced with maçaranduba sediment was 9.24\% and achieved the traction resistance of 14.88MPa [15]. Making the traction resistance limit comparison from these composite materials with the composite material reinforced with tauari fiber was possible to observe that following the mass proportion of $5.22 \%$ the tauari fiber presented a positive difference of $4.2 \mathrm{MPa}$ in comparison with the composite reinforced with maçaranduba sediment and the composite material reinforced with sisal presented a positive difference of $7.08 \mathrm{MPa}$ over the $15 \mathrm{~mm}$ tauari fiber reinforced composite.

Mechanical tests were performed using biocomposites based on Polybutylene Adipate-coTerephthalate - PBAT reinforced with chemical processed and in natura munguba fibers resulted at an increased elasticity module of the composite $(109,0 \pm 7.0 \mathrm{MPa})$ due $20 \%$ of concentration increment of the fiber. The chemical processed fibers increased the chemical interaction of the composite components but did not improved the elasticity module or affected the traction resistance $(10.0 \pm 7.0 \mathrm{MPa})$ neither the rupture strain (392 \pm 40.0$)$ [17].

Another research was performed to evaluate the performance of the composite materials based on epoxy matrix using as reinforcement $15 \mathrm{~m}$ length of banana and sisal fibers resulted in 16.21MPa of traction resistance limit for the banana fiber and in $21.20 \mathrm{MPa}$ of traction resistance limit for the sisal fiber [10]. Comparing these values of traction resistance with the $15 \mathrm{~mm}$ length tauari fibers it is possible to observe that the tauari fiber increased the traction resistance in 2.96MPA unlike the sisal reinforced composite which presented a positive difference of $2.12 \mathrm{MPa}$ over the $15 \mathrm{~mm}$ length tauari fiber.

The research conducted by [18] analyzed the composite materials based on polyurethane and reinforced with curauá fibers under the mass proportions of $5 \%, 10 \%$ and $20 \%$. The tests of mechanical resistance of the composites reinforced with the mass proportion of $5 \%$ of curauá fibers resulted in $14.7 \mathrm{Mpa}$ and in comparison with the composites reinforced with tauari fibers of $5.22 \%$ of mass proportion the mechanical resistance limit achieved was $19.08 \mathrm{MPa}$ resulting in a positive difference of the mechanical resistance of the tauari fiber in $4.38 \mathrm{MPa}$.

This research was compared also with another study of biodegradable polyester reinforced with in natura curauá fibers. The fibers length analyzed respectively were $5 \mathrm{~mm}, 10 \mathrm{~mm}$ and $20 \mathrm{~mm}$ which resulted in the following mechanical resistance limit of 13.60MPa, $17.70 \mathrm{MPa}$ and $14.50 \mathrm{MPa}$ and the chemical processed curauá fibers observed from the mechanical tests to evaluate the traction resistance limits were 14.80MPa, 19.30MPa and 22.20MPa [9].

Observing such results is possible to analyze that the chemical processed curauá fibers improved the traction resistance limit of the composite material in comparison with the in natura processed fiber which resulted in an increased traction resistance of $1.20 \mathrm{MPa}$ for the $5 \mathrm{~mm}$ length curauá fibers, $1.6 \mathrm{MPa}$ for the $10 \mathrm{~mm}$ length composite and $7.7 \mathrm{MPa}$ of mechanical resistance for the $15 \mathrm{~mm}$ length composites.

Comparing the curauá traction resistance results with the tauari traction resistance results is possible to observe that the in natura processed fibers presented good results because the traction resistance of the composites reinforced with $10 \mathrm{~mm}$ length tauari fibers presented a positive difference $1.14 \mathrm{MPa}$ in comparison with the mechanical resistance of the composites reinforced with $10 \mathrm{~mm}$ length curauá fibers and the mechanical resistance results of the composites reinforced with $15 \mathrm{~mm}$ length tauari fibers presented a positive difference of $4.58 \mathrm{MPa}$ in comparison with the mechanical resistance results of the composites with $20 \mathrm{~mm}$ length curauá fibers.

The table 5 displays the summary of the mechanical results comparison of the reinforced composites using tauari fibers with the previous researches results of composite materials reinforced with natural fibers.

\begin{tabular}{|c|c|c|c|c|c|}
\hline Authors & Treatment & Matrix & Reinforcement & $\begin{array}{c}\text { Resistance Limit } \\
\text { (MPa) }\end{array}$ & Difference in MPa (\%) \\
\hline Rodrigues (2008) & In natura & Polyester & Sisal & 26,16 & $+27,06$ \\
\hline Rodrigues (2008) & In natura & Polyester & $\begin{array}{c}\text { Maçaranduba } \\
\text { rwood }\end{array}$ & 14,88 & $-28,22$ \\
\hline $\begin{array}{c}\text { Venkateshwaran e Elayaperumal } \\
(2011)\end{array}$ & In natura & Epoxy & Banana & 16,12 & $-18,33$ \\
\hline Harnnecker et al (2012) & In natura & $\begin{array}{c}\text { Biodegradabla } \\
\text { Polyester }\end{array}$ & Curauá & 17,70 & $-7,79$ \\
\hline Harnnecker et al (2012) & Chemical & $\begin{array}{c}\text { Biodegradable } \\
\text { Polyester }\end{array}$ & Curauá & 19,30 & $+1,13$ \\
\hline Mothé e Araújo (2004) & Chemical & Polyurethane & Curauá & 14,7 & $-29,79$ \\
\hline Present Research & In natura & Polyester & Tavarj & 19,08 & - \\
\hline
\end{tabular}




\section{CONCLUSION}

The manufacturing process of the composite materials reinforced with tauari fiber proceeded using a very simple processing system to obtain the tauari fiber. The manual extraction method applied was the same used by the inhabitants of the area and resulted in a low cost process and preserved the natural mechanical properties of the fiber. The test results of the traction resistance limits presented a value of 19.20MPa which is considered a good performance of the composite material reinforced with continuous and aligned tauari fibers.

The same experiment was performed using particulated tauari fiber and the results were $19.08 \mathrm{MPa}$ of traction resistance for the composite material reinforced with $15 \mathrm{~mm}$ length tauari fiber and $18.84 \mathrm{MPa}$ of traction resistance for the composite material reinforced with $10 \mathrm{~mm}$ length. Comparing the results of the mechanical resistance of the composites reinforced with tauari fibers with other polymeric composites reinforced with natural fiber is possible to declare that the tauari fiber presented good results and the mechanical resistance of this composite material presented improved traction resistance values among the previous researched composites reinforced with in natura processed fibers. Considering the experiments results is possible to state that the natural tauari fiber can be used at the manufacturing process as reinforcement of the industrial composite materials and could be applied at other segments due the mechanical properties confirmed during the laboratory tests. The mechanical properties of the natural fiber of tauari can become a good option to manufacture environment-friendly composites of low cost due the simple extraction process.

\section{ACKNOWLEDGEMENTS}

This research was supported by the Federal University of Pará (UFPA) in partnership with the Galileo Technology Institute (ITEGAM).

\section{REFERENCES}

[1] Marinelli A. L. Desenvolvimento de Compósitos Poliméricos com fibras vegetais biodegradáveis: Uma contribuição para a Sustentabilidade da Amazônia. Polímeros: Ciências e Tecnologia, vol 18, n 2, p. 92-99, 2008.

[2] Faruk, O. et al. Biocomposites reinforced with natural fibers: 2000 - 2010. Progress in Polymer Science.37, p.15521596 (2012).

[3] ASM - AMERICAN SOCIETY FOR METALS handbook: Composites. v. 21. Ohio: The Materials Information Company, 2001.

[4] Oliveira T. A. Avaliação do uso de agente compatibilizante no comportamento mecânico dos compósitos PEBD reforçados com fibras de Coco Verde. Cadernos UniFOA, edição n 14, dezembro/2010.

[5] Callister Jr., William D. Ciência e Engenharia de Materiais: Uma Introdução. 7 Ed. Rio de Janeiro, LTC, 2008.
[6] Lima, E. G. Revisão da aplicação de produtos biopolímeros obtidos pela reciclagem de plásticos em design. Revista Iberoamericana de polímeros. (2009).

[7] Garcia, F. M. Rendimento no Desdobro de Toras de Itaúba (Mezilaurusitauba) e Tauari (Couratariguianensis) segunda a classificação da qualidade da tora. Floresta e Ambiente. 2012 out./dez.;19(4):468-474.

[8] Lemos A. L. Desenvolvimento e Caracterização de Compósitos Poliméricos à Base de Poli(Ácido Lático) e Fibras Naturais. Polímeros, vol 24, n. 2, p. 190-197, 2014.

[9] Harnnecker, F. et al. Biodegradable Polyester-Based Blend Reinforçed with Curauá Fiber: Thermal, Mechanical and Biodegradation Behaviour. Journal of Polymers and the Environment.20, p. 237-244(2012).

[10] Venkateshwaran, N.; Elayaperumal, A. Modeling and evaluation of tensile properties of randomly oriented banana/epoxy composite. Journal of Reinforced Plastics and Compósite. 30, p.1957-1967 (2011).

[11] Saraiva M. P. Laminado de Madeira Reforçado com Fibras Naturais. Dissertação (Mestrado em Engenharia Mecânica). Universidade Federal do Pará. Belém/PA, 2013.

[12] Leão M. A. Fibras de Licuri: Um Reforço Alternativo de Compósitos Ploméricos. Dissertação (Mestrado em Engenharia Mecânica) Universidade Federal do Rio Grande do Sul. Natal/RN, 2008.

[13] Pereira, C. B. Material compósito de poliéster e CipoTitica (Heteropsisjenmani). Dissertação (Graduação em Engenharia Mecânica). Universidade Federal do Pará, 2013.

[14] Costa, D. S. Caracterização de materiais compósitos de matriz poliéster e fibras de bambu, sisal e vidro e híbridos bambu/sisal, bambu/vidro e sisal/vidro. 2012. Dissertação (Mestrado em Engenharia Mecânica), Instituto de Tecnologia, Universidade Federal do Pará, Belém, 2012.

[15] Rodrigues J. S. Comportamento Mecânico de Material Compósito de Matriz Poliéster Reforçado por Sistema Híbrido Fibras Naturais e Resíduos da Indústria de Madeira. Dissertação (Mestrado em Engenharia Mecânica). Universidade Federal do Pará. Belém/Pa, 2008.

[16] ASTM - Standard Test Method for Tensile Properties of Plastic (Metric). ASTM D 638, Annual Book of ASTM Standards, American Society for Testing and Materials, US (1989).

[17] Pinheiro, I. F. Biocompósitos poliméricos de poli (butilenoadipato-co-tereftalato) - pbat e fibra natural de munguba, nativa da Amazônia (pseudobombaxmunguba). Dissertação (Mestrado em Engenharia Química). Faculdade de Engenharia Química da Universidade Estadual de Campinas. Campinas/SP, 2012.

[18] Mothé, C. G.; Araújo, C. R. Caracterização térmica e mecânica de compósitos de poliuretano com fibras de Curauá. Polímeros: Ciência e Tecnologia. v. 14, n. 4, p.274278 (2004). 